\title{
Rescuing Reading: Strategies for Arresting the Decline of Reading in Western Australian Newspapers between the Wars
}

Patrick Buckridge

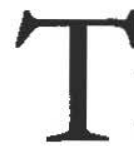

The purpose of this essay is to describe and interpret a cluster of three readerly 'entertainments' conducted in two Perth newspapers, the Western Mail and the West Australian, in the years 1929-1930, and to place them in contexts that enable us to understand them as calculated and connected interventions in a wider campaign of resistance to what was perceived as a decline in recreational reading in this period.

The focus on Perth newspapers allows for more detailed analysis in a limited space than would be possible across a wider print spectrum; but it is not an arbitrary choice. Judging by the frequency of articles in newspapers like the West Australian, the Western Mail and the Daily News, the Perth context does seem to manifest a more pressing anxiety about a decline in the habit of reading, especially in the late 1920 s and early 1930 s, than is evident in the rest of the country, together with a correspondingly stronger and more explicit determination to diagnose and ameliorate the problem. This is not to say that the problem was seen, even in that context, as one that was particular to Western Australia, or even to Australia as a whole. Many of the newspaper articles on this theme cite observations and comments from elsewhere: for example, the Perth Daily News quotes from an address to the Royal Literary Fund in London by the British Foreign Secretary, Sir John Simon, regretting that 'family reading ... has gone out of vogue, and the hustle of these days, with the easy processes of the cinema screen and the broadcast talk, offer to idle minds a dangerous distraction', and, more broadly, that 'reading and that delightful process of subsequent reflection which is of the essence of the pleasure which literature gives to the reader is on the decline' ('Habit').

Similar elegiac or pessimistic reflections on reading can be found-some sourced elsewhere (usually Melbourne, Sydney or London), and some locally composed - throughout the 1920s and early 1930s. The tone ranges from 
cheerful resignation to gloomy lament, and explanations for the decline range from the crossword puzzle craze (blamed by 'a leading London publisher' for a $25 \%$ decline in novel-reading), ${ }^{1}$ to Australia's pioneering tradition, its climate, 'out-doorsy' lifestyle, and 'passion for action', ${ }^{2}$ and the influence of new technologies, in particular radio, the gramophone and cinema. ${ }^{3}$

Not surprisingly, the education system also comes in for its share of responsibility. If young adults are reading fewer books than they used to, it may be that the reading habit is no longer being effectively instilled at school. Speech night addresses by school principals are a traditional source of reflections on this theme, and the one given by Miss Gertrude Walton, longtime headmistress of the Methodist Ladies College in Perth, was reported in full twice, in the West Australian and the Western Mail, during the week before Christmas 1929. In it Walton reports her own first-hand observation 'that reading as recreation is less practised by girls than it was a generation ago', and she seeks for explanations in both the general culture and the school curriculum:

One of the reasons for this decline is to be found in the greater number of distractions, and in the greater popularity of sport. These leave less of that quietness and leisure which are necessary for reading. Another reason is that the school curriculum is much more crowded than it used to be and, in the upper school at least, there is not much time for independent reading. It is true that a good deal of literature is included in the school course, but, unfortunately, books that are prescribed - and particularly, those on which examination questions are to be set - lose some of their attractiveness in a school girl's eyes. In spite of all one's effort to avoid such an association, they are liable to be read with an eye to possible questions, and some of the enjoyment to which they are entitled is lost. ${ }^{5}$

For Walton, arresting the decline of the reading habit meant finding ways to counter the 'common attitude of mental indolence' and the habit, all too quickly formed, of 'shirk[ing] mental exertion'. Schools could provide libraries, reading clubs, dramatic societies and the like. But for such resources to be effective parents' co-operation in the home was essential, 'in encouraging wider reading, and in giving the opportunity for it in a supply of good books

1 'Empire News'; 'Cross-Word Craze.' The crossword craze also caused the removal of dictionaties from the shelves of some smaller public libraries.

2 'Reading,' Daily News (Perth) 22 Dec. 1920: 7.

3 'Reading,' Daily News (Perth), 9 Jun 1921: 5.

4 Gertrude Mary Walton (1881-1951) served as headmistress of MLC (Perth) 1913-1945. See Juliet Ludbrook, 'Walton, Gertrude Mary (1881-1951)', Australian Dictionary of Biograpby (Canberra: National Centre of Biogxaphy, Australian National University, 2002) http://adb.anu.edu.au/biography/walton-gertrude-mary-11955/text21427.

5 'Schoolgirls and Reading: A Declining Habit', West Australian 16 Dec. 1929: 22 and Western Mail 19 Dec. 1929: 14. 
and the necessary leisure and quiet for their enjoyment'. 'In the association with great minds that awaits us in the book world,' Walton enthused,

we shall have given them a joy and a companionship and a refuge that will never fail them. If their school life has made them desire to read, it has done for them far more than in preparing them to pass examinations and to gain diplomas. ${ }^{6}$

Her remedy, in short, was above all to make her girls want to become readersfor-life; and there were various strategies she could use to assist that outcome.

In that same week, similar if more simplistic views were expressed and reported by two other prominent West Australian educationists. Sir Wallace Clubb, Director of Education, used his address to the Princess May Girls' School to urge students to greater 'tenacity of purpose' in their reading (The Modern Schoolgirl') and Dr M.A. Clarke, lecturer in charge of French and German at the University, explicitly conjoined the two speeches - Walton's and Clubb's - into her own trenchant appraisal of the lack of reading experience, ability, interest and curiosity with which her students matriculated ('Children and Reading').

All three commentators identify student reading as a problem to be addressed; and where better to address it than in the controlled environment of the school, in which curricular 'remedies' could be proposed, trialled and implemented? Outside that environment, though, among the general public whose reading was also perceived as declining, the scope for remedial action was clearly more limited. Nonetheless, attempts were constantly being made in this period to intervene actively in the reading habits of the wider Australian public: books of reading-advice 'spiked' noticeably a year on either side of 1930 (Buckridge, 'How to' 79-80); ${ }^{7}$ new literary journals with an explicit 'audience-development' brief started up; ${ }^{8}$ weekly 'literary leaders', both informative and hortatory, were published in most of the major metropolitan broadsheets, including the West Australian; larger, more diverse weekly 'books pages' were introduced in many newspapers (Thomson and Dale 130); and dozens of new book clubs and reading circles were formed.

6 'Schoolgirls and Reading: a Declining Habit,' West Australian 16 Dec. 1929: 22 and Western Mail 19 Dec. 1929: 14.

7 This article contains a checklist of sixty British and American advice-books, of which six first appeated in the years 1929-31, with at least four earlier books reprinted in those same years. Most of these books were available in Australia, but there were also some Australian advice-books, described in Patrick Buckridge, "Serious Reading" between the Wars', A History of the Book in Australia 1891-1945. A National Culture in a Colonised Market, ed. Martyn Lyons and John Arnold (St Lucia: U of Queensland P, 2001) 325-34.

8 The most ambitious and longest-lasting of these was probably the Melbourne-based D.W. Thorpe publication All About Books, on which see David Carter, "Some Means of Learning of the Best New Books": All About Books and the Modern Reader', Austratian Literary Studies 22.3 (May 2006): 329-41. 
The last of these roughly contemporaneous reading interventions new reading circles - is a key element in the Perth context and probably helps to account for the unusually tight coherence and sense of purpose about the whole project of 'rescuing reading', to which, I argue, the Perth newspapers made their distinctive contributions in 1929-30. The unifying and intensifying factor, I believe, was Walter Murdoch. Murdoch had been Professor of English at the University of Western Australia since its foundation in 1913, and was already an immensely popular essayist (Alexander). Believing that 'the habit of reading was one of the marks of the civilised human being, and that no country in which that habit was not widely diffused could call itself a civilized country,', towards the end of 1929 Murdoch devised his own 'reading recovery' plan: a nationwide network of local reading clubs, the Australian Reading Circle (ARC), with branches in every country town and capital city. It would be supported by private and public donations, and run by a Perth-based Central Committee and an executive comprising half a dozen prominent Perth identities including Murdoch and Edith Cowan, and chaired by Wallace Clubb, the Director of Education (the 'tenacity' advocate mentioned above). The Committee Secretary, J.K. Ewers, then a budding author, critic, and literary nationalist, did most of the organisational legwork.

The scheme achieved only moderate success, establishing some forty reading circles in total and surviving as an organisation for about five years. Its reach never extended much beyond Perth and its suburban fringe (Ewers 126). But the importance of the ARC in the present context is precisely that its formation and early progress, which were trumpeted for many months in the WA press, reinforced the sense that the city of Perth, at this particular moment of its history, was registering and responding to a widespread Australian anxiety about the future of reading in unusually clear-sighted, forthright and practical ways.

Murdoch's project is also important in that it occupies an ideological middle ground between the fairly uncompromising traditionalism adopted by the school principals, education bureaucrats and academics quoted above, and the reader-centred newspaper entertainments about to be discussed. In the former case, what was seen as declining was 'good' or 'serious' reading, not necessarily reading in general (much of which was worthless), and what was mainly needed to correct or improve the situation was firm guidance; in the latter case, a much more tolerant and pluralistic attitude to reading prevailed. The cultural ideology of the ARC reflected Murdoch's own deep ambivalence on the whole question of what constituted 'good reading' and how vigorously its acquisition should be required of the general community. For example, in one of his many press releases advocating the formation of

9 'Reading,' Western Argus (Kalgoorlie) 10 Dec. 1929: 2. 
the ARC, he deplores the time wasted 'in reading the trashy stuff that pours from the press in endless profusion, [and] the habit which so many people have acquired of galloping through the latest "thrillers" at breakneck speed'. But on the other hand he has no time for the notion of 'reading as a duty': if reading is not a pleasure it is not worth doing; but without 'the stimulus of fellowship and discussion, and the benefit of expert guidance' - both of which the ARC will provide - that pleasure might not be fully realised.

A really good book does not need to be rammed down people's throats, being in itself one of the jolliest of things - 'not harsh and crabbed as dull fools suppose,' but rich in various delights; ... if one could silence all prigs and pedants and highbrows and everybody who speaks of Literature with a capital $\mathrm{L}$, and let the great writers speak for themselves - using the term great writers with the utmost catholicity - there would be no need to preach, to a reluctant congregation, about the duty of reading. ${ }^{10}$

At this particular moment in history, Murdoch and his Australian Reading Circle, by planting their feet firmly and publicly in both camps, may well have acted as a bridge between the conservatism of the academy and the populism of the newspapers, which might in turn have given both sides more purchase with the general public than they might otherwise have had. At the very least it created a conducive local environment for the newspaper entertainments to succeed.

The first of these entertainments was a competition run by the Western Mail, the weekly broadsheet affiliated with Perth's largest and oldest daily, the West Australian. It was called 'The Best Short Extract' and it ran from January 1929 through to July 1930, awarding a ten shilling prize for 'the best extract of not more than 50 words from a recent novel'. The winning extract was printed each week, boxed, with source and sender, along with three runnersup. Hence, every week for about a year and a half a set of four fictional extracts was published in the paper, representing what the readership of the Western Mail thought of as 'good writing'. Here is an entirely typical example, transcribed in toto:

\section{BEST SHORT EXTRACT}

The Weekly Selection

Each week 'The Western Mail' awards 10/ for the best extract of not more than 50 words from a recent novel ....

The Wise thank God for Work and for Sleep - and pay large premia of the former as Insurance in the latter.

From 'The Snake and the Sword,' by P.C. Wren. Sent by Mrs. E. Yeomans, Graball Farm, via Narembeen.

10 'Reading,' Western Argus (Kalgoorlie) 10 Dec. 1929: 2. 
Yet he bade me go to London, since there a man, rubbing shoulders with all the world, learnt to appraise his own value, and lost the ignorant conceit of himself that a village greatness is apt to breed.

From 'Simon Dale,' by Anthony Hope. Sent by Mrs. Arnold Colliver, Tammin.

It's up to all of us to choose. There are two ways of owning things: - by loving them and not wanting to put them in your pocket, or by grabbing Life and trying to sell it. It's up to all of us to choose.

From 'The Prophetic Marriage,' by Warwick Deeping. Sent by T. Herbert, 101 St. George's Terrace, Perth.

Some wives are never able to connect the two ideas of their husband's business and their own comfort.

From 'Apple Sauce,' by Ina Michael. Sent by D. Woolcott, Stirling, Cranbrook. ('Best Short Extract')

Note the complete absence of suggested criteria for selection: none were ever provided. What does 'best' mean in this context? 'The question seems not to have given the organisers much pause, and the readers seem not to have agonised about it either (or if they did, there was no easy way for them to record their uncertainty). In practice, most readers seem to have opted for impersonal 'pearls of wisdom' and, by implication, for the qualities of wit, humour and profundity usually associated with such writing: thus, of the 320 extracts the vast majority are sage observations about life and love, often clever, humorous, or paradoxical aphorisms, with frequent references to marriage and the 'war of the sexes'. The number of acknowledged individual contributors is roughly 200 , about a quarter of whom contributed two or three extracts each, and one of whom (a Miss M.R. Morcombe of Coorow) contributed ten. They all supply their own titles, names and addresses, and all supply the author and title of the novel. Most of the contributors are women, and most (not all) are from the south-west corner of WA.

There are 188 recent and contemporary authors quoted, of whom about 140 are British. Most of the rest are American, and there are seven Australians, with a handful of other nationalities. A notable feature of the author-list is the large proportion (130, or $69 \%$ ) who are quoted only once, which suggests that, apart from a few current favourites, readers made very diverse book-choices - not as influenced, collectively, by local literary 'gatekeepers' as might have been expected of a geographically circumscribed and (on the face of it) socially homogeneous readership. The most frequently quoted author of all is the English novelist Warwick Deeping (quoted 14 times), followed by British writers John Galsworthy (ten), Michael Arlen and P.C. Wren (seven each) and 'O. Douglas' (Anna Masterton Buchan) (six), with the most popular Americans Maude Harrison (four), Willa Cather and Edith Wharton (three each), and the Australians Dorothy Cottrell (three), A.G. 
Hales (two), and Vance Palmer, Ethel Turner, M. Barnard Eldershaw, Mabel Forrest, and 'Brent of Bin Bin' - not yet unmasked - one each.

It would be unwise to draw any conclusions about longer-term patterns of popularity from these figures; they provide no more than a snapshot of what recent novels a few hundred Western Australians were reading and enjoying at this point in history. The evident dominance by British fiction is noteworthy, though it merely reinforces the findings of recent scholarship in that respect (Lyons; Bremer and Lyons 224; Dolin; Thomson and Dale). More interesting, though, than what the competition reveals about the particular authors these people were reading is what it implies about why and how they were readingwhat they were looking for in a novel - and this comes through even without the opportunity to explain or comment in their own words.

Generally speaking, the published extracts are much more focused on the quality of thought they contain - on its wit, wisdom or astuteness - than on their literary quality as such. Language (that is, diction, style) is admired, if at all, mainly in the aphoristic expression that lends force to the impersonal thought or observation, and there is a fairly limited range of recurrent topics and themes: the ethics of daily life, the nature of love, the problems of marriage and the 'gender war' more broadly, relations between parents and children (the 'generation gap'), the illusions of politics, the importance of humour, and the value of beauty. Some of these can be seen in the example quoted above. Not insignificantly, the most numerous concept-words in the 320-passage corpus are, in descending order, 'man', 'woman', 'love', 'beauty/ beautiful', and 'happy/happiness'.

It would be fair to characterise the reading disposition on show here as 'practical' or 'instrumental': what seemed 'best' in a novel was the evidence of its author's ability to make illuminating and useful observations about human life. In that sense it is essentially the same disposition as that which informs the 'reading-rescue' project itself. And in terms of that project, the purpose of this competition was to assist readers to become aware of the value of their own reading - a value that most of them perceived in instrumental terms.

It may be, however, that as the competition proceeded its organisers began to feel that the wise saws and world-weary aphorisms it was eliciting failed to define adequately the range and intensity of potential reading pleasures; or they may simply have suspected that there was another cohort of readers they were failing to engage. In any case, in June 1929, six months after the start of the 'Best Short Extract' competition, the Mail started another competition called 'Literary Thrills', in which hundred-word extracts were solicited (twice the length of the 'short' ones). This feature ran in parallel indeed on the same page - with 'The Best Short Extract' until 24 July 1930, when they both came to an end. But for the newer competition some specific criteria were supplied, as follows: 'What passage in a recent novel has made 
your blood tingle, caused a creepy feeling down your spine or roused you to the most intense interest? Send along a quotation of not more than 100 words from one of these passages.'. ${ }^{11}$

These stipulations do seem to have tapped into a different, butoverlapping cohort. Of the sixty winning contributing readers (only their extracts were published), only ten also appear among the fifty-word contributors (one of them the bookish Miss Morcombe!). This is perhaps slightly more than might have been expected given the genre-restriction to 'thrillers' implied by the somatic stipulations; and certainly Sax Rohmer, Ambrose Bierce, John Buchan and Edgar Wallace appear among the excerpted authors, as one would expect. But in fact many of the contributions are not from generic thrillers: they include, for example, passages by E.F. Benson, Erich Maria Remarque and Vance Palmer, none of them thriller-writers by any usual definition. The most quoted author (source for six of the sixty passages) is 'Sapper' (aka H.C. McNeile, of 'Bulldog Drummond' fame), followed at some distance by P.C. Wren and Zane Grey. (The full list of authors is given in the Appendix.) But the call for 'intensity' seems to have encouraged readers to focus on the affective power rather than the propositional content of their experience in reading not just thrillers as such but a variety of contemporary genres as well: historical romances, adventure novels, westerns, social realist novels and war memoirs. Power of expression rather than moral or philosophical content seems to be the common factor in the hundred-word passages (and this is perhaps reflected in the frequency of words like 'scream, terror, fear, horror, throat, cry, death' in the quoted passages).

Here is an example from about halfway through the run:

\section{LITERARY THRILIS}

\section{The Best Thrill}

This week's prize is awarded to G. Croxton, Chapman's Corner. Karriedale, who selected the following from 'Wanderer of the Wasteland', by Zane Grey:-

Adam had one flashing thought of the justice of it - one sight of the strange, cold, deadly jewel eyes, one swift sense of the beauty and magnificent spirit of this reptile of the desert, and then horror possessed him. He froze to his marrow. The icy mace of terror had stunned him; and with it had passed the flashing of his intelligence. He was only a fearful animal, fascinated by another dreading death by instinct. And as he collapsed, sagging forward, the rattle-snake struck him in the face with the stinging blow of a red-hot iron. ${ }^{12}$

The larger strategy behind the 'Thrills' competition would seem to have been complementary to the 'Best Extract' competition, in that it was inviting readers to explore - not to describe, analyse or evaluate, but rather to re-

11 'Literary Thrills,' Western Mail 30 May 1929: 12.

12 'Literary Thrills,' Western Mail 28 Nov. 1929: 10. 
experience - the purely affective pleasure of their own reading, and thus to remind themselves how enjoyable reading a book can be. Printed sideby-side, the two competitions could then operate as a useful instrument for modelling the pleasures of reading novels, across a wide spectrum of reading temperaments and dispositions, for those reading the newspaper.

A contemporaneous initiative for engaging Perth readers appeared in the West Australian, the Mail's affiliated daily, in the last fortnight of July 1929. This was a 'plebiscite', so-called, of everyone's six favourite novelists. The idea seems to have come first from a reader, pen-named 'Parnassus'. On the basis of two other 'successful plebiscites' recently conducted by the same newspaper - for the best rose varieties and the best footballers in the state 'Parnassus', in a long letter to the editor, proposed a plebiscite for best novelists since, after all, 'nearly every member of the community, whether old or young, reads'. He or she goes on to offer a conveniently explicit rationale for it, in the form of a two-stage process: 'The advantages of such a plebiscite can readily be understood, for it might help to create a desire to read, and, once this desire is created, a love of good literature would follow' ('Parnassus').

'Parnassus' does not exactly explain the first stage of this process: how making a list of favourite authors might 'create a desire to read'. He does, however, justify the naming of authors rather than single novels, arguing that because 'one's appreciation of a book so often depend[s] on one's mood at the time of reading', authors are more likely than single novels to have given 'the most consistent satisfaction to readers' ('Parnassus'). To get the ball rolling, he offers his own list of six, viz. Alexandre Dumas (père), Charles Dickens, John Galsworthy, Edgar Wallace, R.L. Stevenson and Joseph Conrad. Four days and several submissions later, the anonymous books editor embraced the new plebiscite, announced a time limit for further entries, and acted as race-caller for the rest of the week, collating results and publishing daily updates. After some early jostling for the lead with Galsworthy, Dumas perre and Edgar Wallace, Dickens looked unbeatable with two days to go, heading the field by well over thirty votes, but was then overhauled and headed by Jack London on the final day, coming back to win by just six votes in a photo finish, with Upton Sinclair a close third. (Some last-minute bloc voting by organised labour would have to be suspected: London and Sinclair increased their votes by a factor of three in the last two days!) The final placings, with numbers of votes, were as follows:

First Six

Charles Dickens 146, Jack London 137, Upton Sinclair 130, Alexandre Dumas 88, Edgar Wallace 85, W.M. Thackeray 63.

Second Six

Sir Walter Scott 55, P.C. Wren 49, H.G. Wells 49, Rafael Sabatini 47, John Galsworthy 45, Victor Hugo 42. 
Third six

Zane Grey 40, Baroness Orczy 39, Jeffery Farnol 37, Rider Haggard 37, P.G.

Wodehouse 35, Bernard Shaw 32 [the sole 'ring-in' in a field of novelists].

('Favourite Novelists: Result of Plebiscite')

The horse-racing idiom is largely the newspaper's, not mine, and is clearly a technique for maximising both participation and spectator interest by appealing to the assumed tastes of a broader, less 'cultured', more sporting demographic than the readership of the Western Mail, its weekly stable-mate.

The plebiscite was quite large: 416 entries received (hence 2,496 single votes), and 303 different authors cited. It was not restricted to recent and contemporary novelists; past and present authors, as well as popular and sophisticated ones, were undifferentiated, not only in the aggregated lists but also in the thirty-odd individual lists that were published in the course of the plebiscite. Pen-names were used, though not apparently required. And the first (of eight) Australian authors across the line on the Saturday was probably Nat Gould, who had received eleven votes by the final Thursday, followed by A.G. Hales and Kathleen [sic] Prichard with eight, Guy Boothby with two, and Ethel Turner, Bernard Cronin, 'Steele Rudd' and Mary Grant Bruce each with one. ${ }^{13}$ In a lengthy unsigned 'Commentary' on the plebiscite published the following Monday (probably by Walter Murdoch), Dickens' triumphant win was approvingly endorsed, and the strong performances by Jack London, Upton Sinclair and Edgar Wallace ruefully deplored, along with the voters' evident lack of interest in Defoe, Sterne, Jane Austen, and Henry Fielding, the last of whom 'wrote incontestably the greatest novel in the English language. ${ }^{14}$

This was a rerun of a similar, but even larger event - not actually called a plebiscite - conducted by the Melbourne Argus nearly a quarter of a century earlier, in February-March 1905, in search of the 'twelve best novels of the Victoria-Edward period' (Wollaston). Over one thousand voters took part in this event, and it would certainly have been remembered by Walter Murdoch, who was in the Melbourne English Department at the time, and wrote the corresponding Commentary. The winner of that earlier event was David Copperfield, and two Australian novels, His Natural Life and Robbery under Arms, came in at numbers eight and eighteen respectively ('Twelve Best Novels').

I remarked earlier that 'Parnassus', the proposer of the West Australian's plebiscite, had not explained the mechanism by which it might 'create a desire

13 No full final listing was published. The last full listing of authors appeared, with numbers of votes, on the Thursday, two days before the final result ("Favourite Novelists: Plebiscite to Close on Saturday,' West Australian 1 Aug. 1929: 20.) At that time a total of 1,168 votes had been recorded, less than half the final total. The positions of the Australians on the list might therefore have changed somewhat by the Saturday - but not enough to enter the first eighteen. Clearly a considerable last-minute voting surge occurred.

14 West Austratian 1 Aug. 1929: 20. 
to read', though apparently believing that it could do so. Perhaps 'Parnassus' was assuming simply that intending contributors would wish to refresh or extend their novel-reading in order to make a respectably informed choice; or again, that readers of the newspaper would learn of the existence of novelists they had not heard of. 'Parnassus' may also have felt that the project would stimulate some discussion and debate on reading, both in the pages of the West Australian and in the wider community: it is difficult to gauge the extent of outside discussion, but there were indeed some strong opinions and spirited disagreements among the contributors on the relative worth of older works and 'present-day pot-boilers', on whether 'foreign' authors should be included or not, on the difficulty of restricting each contributor's number to six, and on the promiscuous juxtaposition of canonical and popular authors in some people's lists. ${ }^{15} \mathrm{On}$ all such issues the editor offered no comment.

I suspect, however, that the main mechanism 'Parnassus' had in mind may have had to do with the power of lists themselves to create a sense of real connection with the larger, more complex and substantial entities on which they draw - in this case, the whole world of fiction. Lists, it has been suggested, are 'a kind of intellectual comfort food', providing 'the pleasures of taxonomy and axiology without many of the demands of rigorous analysis, whether we make and use our own lists, or employ the lists of others' (Hall 56). The gradually emerging result of the West Australian plebiscite, then - an extended list in which Jane Austen, Thackeray and Meredith rubbed shoulders willy-nilly with 'Sapper', Ruby Ayres and E. Phillips Oppenheim rode roughshod over traditional literary hierarchies and categories, and might well have communicated to the local reading community - contributors and readers alike - a new sense of welcoming access, even of belonging and ownership, in relation to the 'world of books'.

To protect and intensify this sense of belonging in the world of books, it is noteworthy that the Western Mail created an autonomous space called, precisely, 'The World of Books' (Fig. 1). Robert Thomson and Leigh Dale, in their pilot survey of the literary content in Australian newspapers through December 1930, report that several of the newspapers in their sample of 32 had a regular literary page of this kind: a 'designated space' containing not only reviews, but also 'literary essays, literary criticism, literary chit-chat and other material, including poems and anecdotes' (130) - to which list I would add literary history and literary biography. Of these pages the one entitled 'Books and Writers' that ran in the Adelaide Register for seven years (Feb. 1922-Dec. 1928) most closely resembles the Western Mails 'World of Books', and may have been its model. Both pages provided a remarkably rich and varied menu, creating a sphere of comfortable sociability in which readers of

15 'Favourite Novelists,' West Australian 24 July 1929: 16; 25 July 1929: 18; and 26 July 1929: 22. 
all classes could feel at home in a welcoming literary environment presided over by a cultivated, tolerant and pseudonymous literary authority - 'J. Penn' from 'The Library Table' in Adelaide, and 'John Lester' 'From My Library Chair' in Perth. The Western Mails 'World of Books' lasted less than five years, from February 1927 to September 1931 - roughly coterminous, that is to say, with the 'reading-rescue' campaign I have been describing. The West Australian, on the other hand, ran a 'Life and Letters' feature every Saturday for 32 years (1923-54) which - although it nearly always included a short essay or review by Sir Walter Murdoch - only ever extended to half a page, sharing the rest of the page with music, arts and theatre reviews, and never seems as varied, welcoming and interesting - as 'world-like' - as its weekly counterpart. In that sense it does not seem to have been integral to the reading campaign of 1929-30.

The impulse behind these varied but inter-related initiatives in the Perth newspapers in 1929-30 was to rescue the habit of book-reading from what was widely perceived as its decline and imminent disappearance. The newspapers' rescue strategy, essentially, was to make people want to read books, by reminding them how much they enjoyed reading, and what they liked about it, and by engaging them in activities with the potential to make them feel as if they belonged in the world of books - in effect interpellating them as members of the institution of reading.

It was of course not the first time that the popular print media had been used for cultural advocacy. There were well-established Victorian traditions, extending into the early twentieth century in Britain and Australia, of using the 'quality press' to promote the appreciation of classic literature and respect for high culture. But this was not what the Perth campaign was about, however much some of the more educated and cultivated participants (including, it would seem, its proposer, 'Parnassus', and its anonymous final commentator, probably Murdoch) may have wished that it were; nor, for that matter, does this seem to have been the focus for most of the other newspapers, magazines and reading circles around Australia in the late 1920s and early 1930s. The concept of 'good reading' itself, as it developed in the Women's Weekly, for example, did not mean 'great literature' in the canonical sense, but something closer to 'enjoyable reading'; and indeed for many Weekly readers it clearly embraced popular romance and contemporary thrillers (Buckridge, 'Good Reading' 36-37). In similar fashion, the Perth newspapers' reading-recovery campaign - conducted just a few years before the Weekly came onto the Australian scene - defied (or sacrificed) canonicity in favour of inclusiveness and a deliberate suspension of literary hierarchy based on any principle but popularity. The participants were not being exhorted to read better books, but rather to be aware of, to value, and to want to preserve, the pleasure and happiness they derived from their own preferred reading, whatever it might 
be. Whether these strategies actually affected reading habits at the time in the way I believe they were aiming to do would seem to be almost impossible to estimate.

\section{APPENDIX}

West Australian Plebiscite, 25 July-3 August 1929

Full List of Voted Authors, as at Thursday 1 August

More than 30 votes

Charles Dickens, Alexandre Dumas, Edgar Wallace, Jack London, Upton Sinclair, William M. Thackeray.

\section{$10-30$ votes}

John Galsworthy, Rafael Sabatini, Sir Walter Scott, Victor Hugo, P.C. Wren, H.G. Wells, Rider Haggard, Jeffrey Farnol, P.G. Wodehouse, Rudyard Kipling, Baroness Orczy, A. Conan Doyle, Bernard Shaw, Zane Grey, Anatole France, Vicente Blasco Ibanez, R.L. Stevenson, Mark Twain, Marie Corelli, Nat Gould, George Eliot, Sir Philip Gibbs, Leo Tolstoy, Lord Lytton, Hall Caine, Maxim Gorky.

\section{5-9 votes}

Sinclair Lewis, Joseph Conrad, Ethel M. Dell, O. Henry, Warwick Deeping, A.G. Hales, C.E. Mulford, Thomas Hardy, W.L. George, Kathleen [sic] Prichard, Peter B. Kyle, Marie Oemler, Charlotte Brontë, Harold Bell Wright, Gene Stratton Porter, Bret Harte, Sir James Barrie, Charles Reade, William J. Locke, Grant Allen, John Buchan, Jules Verne, Emile Zola, Theodore Dreiser, Elinor Glyn, A.S.M. Hutchinson, Leonard Merrick, N.G. Hagen, Rex Beach.

\section{$2-4$ votes}

Stephen Leacock, Charles Garvice, George Meredith, E. Phillips Oppenheim, Mary Johnston, William McLeod Raine, Aldous Huxley, Arnold Bennett, Ian Hay, Olive Schreiner, Edward Bellamy, Jackson Gregory, L. Cohen, Harrison Ainsworth, Joseph Lincoln, Ouida, Winston Churchill, James Oliver Curwood, Frank L. Packard, D.K. Broster, Mrs. Henry Woods, Gilbert Frankau, Radclyffe Hall, G.K. Chesterton, Ruby M. Ayres, Charles Kingsley, Joseph Hocking, Michael Arlen, Edgar Allen Poe, Captain Marryat, Stanley Weyman, Max Pemberton, Ernest Raymond, Berta Buck, William Le Queux, Jane Austen, David Grayson, Maurice Hewlett, Storm Jamieson [sic], Anthony Hope, Louise Jordan Miln, Arthur Ransome, William de Morgans, E.V. Lucas, Henry Fielding, Thomas Carlyle, The Gentleman with the Duster, W.S. Gilbert, A.A. Milne, Gilbert Parker, Christopher Morley, Gustave Flaubert, Patricia Wentworth, A.E.W. Mason, Rolf Boldrewood, Georgette Heyer, R.M. Ballantyne, Grace Richmond, Guy Boothby, Oliver Sandys, Florence L. Barclay, R.H. Mottram, 
Cutliffe Hyne, Frances Bellamy, Richard Dehan, Lion Feuchtwanget, John Masefield, Dornford Yates, Daniel Defoe, Cecil Roberts, Henri Barbusse, N. Bowen.

1 vote

Mary Borden, Dorothy Canfield, Margaret Kennedy, Stephen McKenna, Ethel Mannin, Robert Hitchens, Sylvia Thompson, Booth Tarkington, Margot Asquith, L.M. Montgomery, Mary Roberts Rinehart, Joan Sutherland, Harold Macgrath, Louis Joseph Vance, George Barr McCutcheon, Dale Collins, D.H. Laurence [sic], Ethel Turner, Ridgwell Cullum, Effie Rowlands, Austin Freeman, Denise Robins, Sheila McDonald, Nora K. Strange, Margaret Pedlar, W.W. Jacobs, W. Jenkins, J.O. Curwin, F. Cooper, Carl van Vechten, Paul Morand, Bernard Cronin, Steele Rudd, Andrew Soutar, Rupert Hughes, Victor Bridges, Sweig [Stefan Zweig?], E.M. Barrington, Allan Raine, Wilkie Collins, A.P. Herbert, G.R. Vickery, Paul Trent, Louis Tracy, Charles Alden Seltzer, Sax Rohmer, Richmal Crompton, Headon Hill, Louis Gerard, Compton Mackenzie, Honoré de Balzac, Jean Webster, J.H. Currie, Martha Ostenso, Beverley Nichols, Joseph Hatton, F. Britten Austin, Miguel de Cervantes, J.S. Fletcher, Herman Melville, Sinclair Gluck, George Ogden, H.A. Vachell, Richard Barham, Algernon Blackwood, Will Levington Comfort, Maurice Baring, F.W. Wallace, Lord Frederic Hamilton, Max Brand, Effie Rowlands, Herbert Jenkins, Mary Grant Bruce, Adam Beck, Talbot Mundy, Frank Crane, May Edington, Mary Webb, Naomi Royd-Smith, Muriel Hine, George A. Birmingham, Sir Harry Vane Tempest, Eileen Carmody, Phyllis L. Greene, Eve Meredith, John Oxenham, H. Seton Merriman, James Branch Cabell, Silas Hocking, Susan Warner.

\section{WORKS CITED}

Alexander, Fred. 'Murdoch, Sir Walter Logie (1874-1970).' Australian Dictionary of Biography. National Centre of Biography, Australian National University, http://adb.anu.edu.au/biography/murdoch-sir-walter-logie-7698/text13477, publ. in hardcopy 1986, accessed 10 Nov. 2014.

'Best Short Extract.' Western Mail2 Jan. 1930: 9.

Bremer, Annette, and Martyn Lyons. 'Mechanics Institute Libraries: The Readers Demand Fiction.' A History of the Book in Australia 1891-1945. A National Culture in a Colonised Market. Ed. Martyn Lyons and John Arnold. St Lucia: U of Queensland P, 2001. 209-25.

Buckridge, Patrick. "How to Read Books": Reading-Advice Books in Britain and America 1870-1960.' BSANZ Bulletin 26.2 (2002): 67-80.

__. "Good Reading" in the Australian Women's Weekly, 1933-1970.' JASAL 1.1 (2002): 32-43.

- - "The Age of Appreciation: Reading and Teaching Classic Literature in Australia in the Early 'Twentieth Century.' Australian Literary Studies 22.3 (May 2006): 342-56.

'Children and Reading: University Lecturer's Criticism.' West Australian 19 Dec. 1929: 9. 
'Commentary' [Walter Murdoch?]. West Australian 1 Aug. 1929: 20.

'Cross-Word Craze. Raid on Dictionaries. Decline in Novel-Reading.' Daily News (Perth) 20 Feb. 1925: 2.

Dolin, Tim. 'The Secret Reading Life of Us.' Readers, Writers, Publishers: Essays and Poems. Ed. Brian Matthews. Canberra: Australian Academy of the Humanities, 2004. 115-34.

'Empire News.' Western Mail 26 Feb. 1925: 20.

Ewers, John Keith. Long Enough for a Joke: An Autobiography. Fremantle: Fremantle Arts Centre, 1983.

'Favourite Novelists.' West Australian 24 July 1929: 16.

'Favourite Novelists.' West Australian 25 July 1929: 18.

'Favourite Novelists.' West Australian 26 July 1929: 22.

'Favourite Novelists: Result of Plebiscite. Charles Dickens Heads the List.' West Australian 3 Aug. 1929: 20.

'Habit of Reading.' Daily News (Perth) 5 Nov. 1932: 12.

Hall, Dennis. 'Listomania: The List as Popular Culture Icon.' Studies in Popular Culture 28.1 (Oct. 2005): 49-59.

'Literary Thrills.' Western Mail 30 May 1929: 12.

'Literary Thrills.' Western Mail 28 Nov. 1929: 10.

Lyons, Martyn. 'Britain's Largest Export Market.' A History of the Book in Australia 1891-1945. A National Culture in a Colonised Market. Ed. Martyn Lyons and John Arnold. St Lucia: U of Queensland P, 2001. 19-26.

Macintyre, Stuart. The Succeeding Age. The Oxford History of Australia, Volume 4, $1901-$ 1942. Melbourne: Oxford UP, 1986.

'The Modern Schoolgirl: The Criticism of Educationists.' West Australian 16 Dec. 1929: 20.

'Parnassus.' 'Favourite Novelists: A Correspondent's Selection.' West Australian 22 July 1929: 16.

'Reading.' Daily News (Perth) 22 Dec. 1920: 7.

'Reading.' Daily News (Perth) 9 June 1921: 5.

'Reading.' Western Argus (Kalgoorlie) 10 Dec. 1929: 2.

'Schoolgirls and Reading: A Declining Habit.' West Australian 16 Dec. 1929: 22.

'Schoolgirls and Reading: A Declining Habit.' Western Mail 19 Dec. 1929: 14.

Thomson, Robert, and Leigh Dale. 'Books in Selected Australian Newspapers, December 1930.' Resourceful Reading: The New Empiricism, eResearch, and Australian Literary Culture. Ed. Katherine Bode and Robert Dixon. Sydney: Sydney UP, 2009. 119-41.

'Twelve Best Novels. Final Analysis. Result of the Voting.' Argus (Melbourne) 23 Mar. 1905: 7.

Wollaston, G.E. 'Twelve Best Novels.' Argus (Melbourne) 22 Feb. 1905: 5. 